Borneo Journal of Science \& Technology, Volume (3), Issue (1), Pages: 93-98

DOI: http://doi.org/10.3570/bjost.2021.3.1-12

e-ISSN: 2672-7439

(c) 2018, UCTS Publisher.

Submitted: $14^{\text {th }}$ November $2020 \quad$ Accepted: $05^{\text {th }}$ January $2021 \quad$ Published: $31^{\text {st }}$ January 2021

\title{
Effectiveness of Sago waste as Partial Cement Replacement in Sibu Peat Stabilisation
}

\author{
Syazie Nordzaima Ali Mohammad, Wong Khoon Ming, Grand Tang Yin Sam and Yeap Xiaoxian \\ School of Engineering and Technology, University College of Technology Sarawak (UCTS), \\ 96000 Sibu, Sarawak, Malaysia.
}

\begin{abstract}
This paper focused on determining and evaluating the effectiveness of sago waste as partial cement replacement in Sibu peat stabilization. Cement stabilisation is one of the practical methods nowadays to stabilise peat since peat undergoes excessive settlement after the completion of construction works. However, adding a large amount of cement is not an economical method when the cover area is wide. Sago's palm is widely planted in Mukah area and tons of Sago effluent is thrown into the river every day without further treatment. Increasing concern about the management of sago waste creates awareness in investigating its potential ability in peat stabilisation. This research will emphases on the usage of Sago waste as partial cement substitution in peat stabilisation. Sago waste, Ordinary Portland Cement $(\mathrm{OPC})$ and calcium chloride $(\mathrm{CaCl} 2)$ are materials used to stabilise the peat through laboratory experiments. The optimal mix design of the peat specimen was then tested in Unconfined Compressive Strength Test. Stabilised peat then further tested for elementary composition and microstructure by using Energy Dispersive X-ray (EDX) and Scanning Electron Microscope (SEM). It can be concluded that stabilised peat which is composed of 25 percent partial replacement of OPC with Sago waste discovered to have peak unconfined compression strength and measured to be about 17 times higher than untreated peat sample.
\end{abstract}

Keywords: Peat Stabilisation, Partial Cement replacement, Sago waste, Unconfined Compressive Strength, Scanning Electron Microscope

\section{INTRODUCTION}

Peat is distributed throughout the world. The land area of Malaysia covered with peat is about 3 million hectares areas of peat [1]. Sibu and Mukah division has about 0.6 million hectares of peat area, which is the biggest in Malaysia [2]. Table 1 shows the area of peat soil in Malaysia. Peat poses a serious problem in construction due to its primary and long-term settlement, even if the moderate load is applied to it [3].

Table 1: The area of peat soil in Malaysia region [1]

\begin{tabular}{|l|c|c|}
\hline Region & $\begin{array}{c}\text { Total Area of } \\
\text { Peat (ha) }\end{array}$ & $\begin{array}{c}\text { Percentage } \\
(\mathbf{\%})\end{array}$ \\
\hline Sarawak & $1,698,847$ & 69.08 \\
\hline $\begin{array}{l}\text { Peninsular } \\
\text { Malaysia }\end{array}$ & 642,918 & 26.16 \\
\hline Sabah & 116,965 & 4.76 \\
\hline Total & \multicolumn{2}{|c|}{$\mathbf{2 , 4 5 7 , 7 3 0}$} \\
\hline
\end{tabular}

The demand for construction in Sibu keeps increasing because of the rapid construction in these few years. The construction on the peatland always the last option for engineering because it is cost consuming and the effectiveness of the soil treatment is questionable. However, the lack of good soil quality in Sibu encourages research on the effectiveness of the stabilisation of the peat.

Construction issues usually occur in Sibu due to peat soil. Ground subsidence has several issues with the settling of frequent soil, repaired building structure or foundations, and failures in infrastructure. This produces drainage with a negative gradient and flooding in most of Sibu area. Besides, embankment design and construction on exceptionally soft and compressible peat are the issues that usually focus on by the researcher all around the world. It will encounter a soil environment of high moisture content, high compressibility, low shear strength, and high-water level [4].

Peat tends to be further broken down and its rate of decomposition could be increased by regulating influence factors such as oxygen supply, $\mathrm{C}: \mathrm{N}$ ratio, $\mathrm{pH}$ level, and optimum temperature. The high-water content makes the ground undesirable for development. The water content of peat typically ranges from 500 percent to 2000 percent, whereas the water content in the peat test is normally lower than 500 percent [5].

\footnotetext{
Corresponding Author: Syazie Nordzaima Ali Mohammad, University College of Technology Sarawak (UCTS),

Email: syazie@ucts.edu.my
} 
Peat has higher organic content over $75 \%$. Development of the peat soil surface attributed to a higher level of residual crop deposition and a lower rate of decomposition. Peat is an accumulation of remains of disintegrated plants that were maintained under insufficient aeration conditions and large water content. Peat development is more effective when the environment is waterlogged, with heavy precipitation and poor permeability, regardless of latitude or altitude [5].

Some of the researchers focus on the ability of the cement to stabilise the peat. The problem meet is high organic content of peat will retard the proper hydration of the binder because of the humic acid from the peat. Humic acid only can be neutralised by adding a large amount of cement into it $[4,5]$. However, this method is unfriendly and uneconomical.

Cement is the source of about $8 \%$ of the world's carbon dioxide $(\mathrm{CO} 2)$ emission and expected to reach 4.8 billion metric tons by $2030[6,7]$. The usage of cement in construction must be decreased to lower the emission of carbon dioxide in the future. The usage of cement in peat stabilisation is also not practical for a huge project because involves lots of costs.

Organic soil can delay or prevent proper binder hydration in binder soil mixtures, such as cement, and become insufficient to stabilize peat soil. The reaction between humic acid and calcium ions produced during the hydration process of cement makes the crystallization of calcium difficult. Calcium crystallization is an important process because the peat soil-cement mixture plays an important role in improving its strength [4].

$$
\begin{aligned}
& \text { Cement }+\mathrm{H}_{2} \mathrm{O}=3 \mathrm{CaO} .2 \mathrm{SiO}_{2.3 \mathrm{H}_{2} \mathrm{O}}+\mathrm{Ca}(\mathrm{OH})_{2}-- \\
&--(1) \\
& \mathrm{Ca}(\mathrm{OH})_{2}+\text { Pozzolan }+\mathrm{H}_{2} \mathrm{O} \\
&=3 \mathrm{CaO} .2 \mathrm{SiO}_{2.3 \mathrm{H}_{2} \mathrm{O}}--(2)
\end{aligned}
$$

Equations 1 and 2 show the overall chemical reactions with water between cement and pozzolans. Calcium silica hydrate (3CaO.2Si $3 \mathrm{O})$, also known as tobermorite gels, is produced as cement mixes in peat with water. The gel serves as an additive which ties soil particles together and captures them. Humic acid in peat soil can lead to insoluble calcium humic acid with calcium ions. The production of insoluble humic acid prevents the reaction between calcium hydroxide $(\mathrm{Ca})$ and peat soil as a secondary pozzolanic reaction. Without the involvement of secondary pozzolanic reaction, poor shear strength increases in the soil-cement mixture.

In this study, pozzolans were added to stabilise the peat. Pozzolans is material which consists of silica, iron and aluminium ion that can create pozzolans reaction. In peat stabilisation, small quantities of pozzolans are added into the concrete to promote a secondary pozzolanic reaction that can counterbalance the humic acid in the peat. In short, pozzolans will densify the peat and further increase its strength [4].

Pozzolans used in this research are sago waste. This is the waste disposal from the sago factory because it has no value and not much effort to turn the sago waste into a valuable product. Disposal of sago waste into the river in Mukah creates a negative impact on the environment, such as air pollution and water pollution, and finally affecting the local ecosystem.

Indonesia is the biggest sago palm region, followed by Papua New Guinea and Malaysia as shown in Table 2. Malaysia becomes the third-largest sago producer in the world. From the Table above, we can know that Sago has widely found in Sarawak if compare to Sabah and West Malaysia. From Figure 2, sago crops are found widely in Mukah and Betong Division alluvial soil and swampy forest along the lower stretches of the Balingian, Mukah, Oya, Igan, Lupar, Saribas, and Rimbas Rivers in Sarawak [8].

Based on the data produced by the Sarawak Department of Agriculture in 2012, an estimated 11,112 ha., 28,169 ha., 4,306 ha, and 3,149 ha. of sago were grown in all four districts of the Mukah division, namely Mukah, Dalat, Matu, and Daro. Small-scale sago farmers planted 43,426 ha. of land with sago in Sarawak and commercial sago planted 24,531 ha. of land. Sago is the next viable commodity crop in Sarawak given that this palm can grow around 1.69 million ha. of peat soil [9].

Therefore, the alternative binder that is environmentally friendly and sustainable management must be determined and replace with cement partially or even completely. Utilisation of sago waste in the stabilisation of peat is the best choice for research because sago waste can be easily taken from local. So, the objective of the study is to evaluate the effectiveness of the Sago waste as partial cement replacement in local peat stabilisation. It is expected that the optimum mix design can be applied to shallow peat layer and even perform better strength than cement itself in peat stabilisation (C100).

\section{MATERIALS AND METHODS}

The materials that had been used are peat, Ordinary Portland Cement (OPC), Sago waste, and Calcium Chloride $(\mathrm{CaCl} 2)$. Peat sample is taken from the area beside Stadium Tun Zaidi, Sibu, Sarawak, and Sago waste then obtained from Shimada Sago Chemical Sdn. Bhd, Dalat, Sarawak.

For the laboratory experimental samples, peat was excavated to a depth of $1 \mathrm{~m}$ from the ground surface. OPC is the main binder and Sago waste is acts as a "sub" binder in the peat specimen. Calcium chloride was then added to it to speed up the chemical reaction of the 
stabilised peat. During the mix design, particle size of peat and Sago waste, calcium chloride dosage, and curing duration constant throughout the experiment.

Before proceeding to the Unconfined Compression Strength (UCS) test, various laboratory tests will be carried out to ensure the soil sample taken is peat. The entire laboratory test regulation and standards were shown in Table 2.

Energy Dispersive X-rays (EDX) was then conducted to provide chemical evidence on the existence of calcium which is the major element of the cementation products in the stabilised peat. Furthermore, Scanning Electron Microscope (SEM) was then conducted to give micro visual evidence on the cementation and void refinement of the peat sample.

Table 2: Standard for laboratory tests

\begin{tabular}{ll}
\hline \multicolumn{1}{c}{ Laboratory Test } & \multicolumn{1}{c}{ Standards } \\
\hline Particle Size Distribution & ASTM D422 Standard \\
Moisture content & ASTM D2974 Standard \\
Organic content & ASTM D2974 Standard \\
Fiber content & ASTM D1997 Standard \\
Specific Gravity & ASTM D854 Standard \\
pH value & BS1337: Part 3:1990 \\
Liquid Limit & ASTM D4318 \\
Unconfined Compression & ASTM D2166 \\
Strength & \\
\hline
\end{tabular}

\section{Mix Design of Peat Specimen}

Mix Design of stabilised peat for UC testing is shown in Table 3. In the mix design of the peat specimen, half of its weight comprises peat and another half comprises the binder of OPC and sago waste. Particle size distribution for peat and Sago waste for forming mix design are shown in Table 4 and Table 5 , respectively. The particle size of the peat and Sago waste kept constant for every sample of mix design to ensure the binder composition is the only factor that affects the result of the UCS test.

Table 3: Laboratory mix design

\begin{tabular}{ccc}
\hline $\begin{array}{c}\text { Type of } \\
\text { test }\end{array}$ & $\begin{array}{c}\text { Duration } \\
\text { (days) }\end{array}$ & Binder composition \\
\hline & & $100 \% \mathrm{OPC}(\mathrm{C} 100)$ \\
& & $95 \% \mathrm{OPC} ; 5 \%$ Sago waste(C95S5) \\
& & $90 \% \mathrm{OPC} ; 10 \%$ Sago waste $(\mathrm{C} 90 \mathrm{~S} 10)$ \\
UC & 7 & 85\%OPC;15\% Sago waste (C85S15) \\
& & 80\%OPC;20\% Sago waste (C80S20) \\
& & $75 \% \mathrm{OPC} ; 25 \%$ Sago waste (C75S25) \\
& & $70 \% \mathrm{OPC} ; 30 \%$ Sago waste (C70S30) \\
\hline
\end{tabular}

Table 4: Particle size distribution of Peat

\begin{tabular}{ccc}
\hline Type of test & $\begin{array}{c}\text { Particle size of peat } \\
(\mathbf{m m})\end{array}$ & $\begin{array}{c}\text { Percentage } \\
(\mathbf{\%})\end{array}$ \\
\hline \multirow{3}{*}{ UC } & 0.075 to pan & 20 \\
& $0.015-0.075$ & 30 \\
& $0.425-0.015$ & 50 \\
\hline
\end{tabular}

Preparation of the peat specimen for the Unconfined Compression (UC) test will be done by filling and compacting the specimen in five equal layers. The cylinder mold has a size of $38 \mathrm{~mm}$ internal diameter and $79 \mathrm{~mm}$ height. The compacted peat specimen was then cured in the water for 7 days and ready for the UC test.

Table 5: Particle size distribution of Sago waste

\begin{tabular}{ccc}
\hline Type of test & $\begin{array}{c}\text { Particle size of Sago } \\
\text { waste }(\mathbf{m m})\end{array}$ & $\begin{array}{c}\text { Percentage } \\
(\boldsymbol{\%})\end{array}$ \\
\hline \multirow{2}{*}{ UC } & 0.075 to pan & 40 \\
& $0.015-0.075$ & 60 \\
\hline
\end{tabular}

\section{RESULTS AND DISCUSSION}

\section{Physical properties of peat}

Table 6: Physical properties of the peat sample obtained from Stadium Tun Zaidi, Sibu

\begin{tabular}{ll}
\multicolumn{1}{c}{ Physical properties } & Project Results \\
\hline Moisture Content Test & $618.72 \%$ \\
Organic Content Test & $79.9 \%$ \\
Ash Content Test & $20.1 \%$ \\
Fiber Content Test & $42.16 \%$ \\
pH Test & $5.92-6.5$ \\
Specific Gravity Test & $1.01-1.05$ \\
Liquid Limit Test & $125 \%$ \\
\hline
\end{tabular}

Table 6 shows the results of the laboratory test carried out at the University College of Technology Sarawak (UCTS). pH test gives the value of smaller than 7, which is acidic soil. The soil is taken considered peat because of its high organic content and fiber content. Soil sample with an organic content greater than $75 \%$ proved that it is peat soil. Peat is categorized as Hemic peat since fiber content lies between $33 \%$ to $67 \%$. Specific Gravity lies between 1.01-1.05 as standard Specific Gravity lies between 1.07-1.7. [8]

Moisture Content of $618.73 \%$ indicates that the soil is peat because the peat lies between $500 \%-2000 \%$. [9] As result, the soil sample got from Tun Zaidi Stadium is peat with the classification of Hemic Peat and also Degree of Humification of H5 by referring to the Von Post Classification Test, Organic Content Test, and also Fiber Content Test.

\section{Unconfined Compression (UC) test}

Figure 1 shows the experimental results of the effect of Sago waste on the unconfined compressive strength of the stabilized peat. An optimal unconfined compressive strength of the stabilized peat was evaluated based on the results of unconfined compression tests on the stabilized peat specimen with partial cement replacement of the cement with Sago waste that varies from 5\% to $30 \%$ as shown in Table 2. 


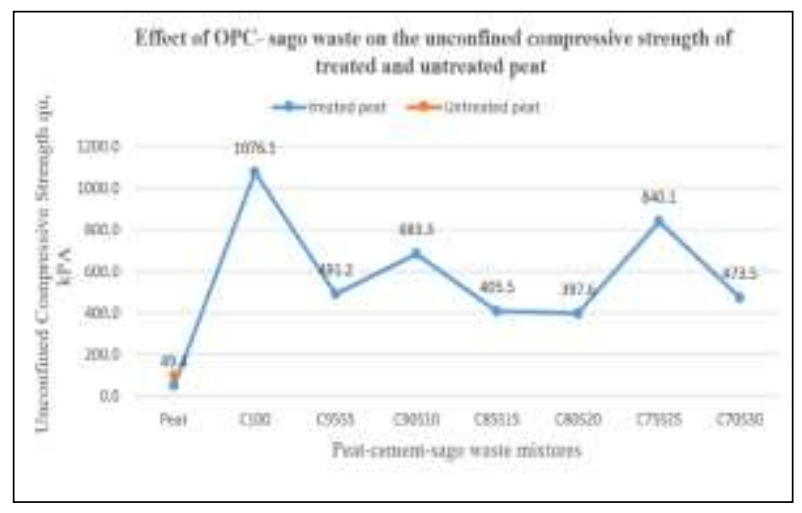

Figure 1: Effect of OPC-Sago waste on the unconfined compression strengtha of the untreated and treated peat

It can be observed that test specimen with $25 \%$ partial cement replacement of OPC with Sago waste has the highest unconfined compressive strength of $840 \mathrm{kPa}$ and was discovered to be 17 times than UCS of untreated peat specimen, which has only achieved UC strength of $49 \mathrm{kPa}$. ASTM 4609 states that an increase in unconfined compressive strength of $345 \mathrm{kPa}$ or more must be achieved for a treatment to be considered effective. The peat specimen with partial cement replacement with sago waste is a success because it can cure the stabilized peat with 17 times of UCS of untreated peat specimen.

Figure 1 reveals that C75S25 mix composition has the highest unconfined compressive strength, which has the value of $840 \mathrm{kPa}$. However, C75S25 mix composition of the peat sample is lower than C100 mix composition, which is 1076kPA. C75S25 mix composition has higher UCS than other mix composition because of the Calcium and Carbon element as shown in Table 8. The chemical evidence on the existence of calcium which is the major element of cementation products in the stabilized peat conducted by using EDX and shown in Table 8. In short, Sago waste is not suitable as pozzolan material to replace the cement partially in peat stabilization since UCS of mix design peat sample varies from $5 \%$ to $30 \%$ is lower than $\mathrm{C} 100$ peat specimen. This indicates that the optimal mix design of $25 \%$ sago waste cannot be applied to stabilize the peat in such a way that the pozzolans cannot fill up the pore spaces of the cemented soil.

\section{Energy Dispersive X -ray Spectrometer (EDX)}

Based on ASTM 1975, Pozzolanic materials are siliceous and aluminous materials, possessing little or no cementitious value and react chemically in the presence of moisture with calcium hydroxide from cement to form a compound possessing cementitious properties. From Table 7, peat has an exceptionally low content of pozzolanic materials with $1.56 \% \mathrm{Al}$ and $2.5 \% \mathrm{Si}$.
Table 7: EDX test results of the element contained in materials used for peat specimen

\begin{tabular}{cccc}
\hline Element & $\begin{array}{c}\text { Untreated Peat, } \\
\text { weight percentage } \\
(\%)\end{array}$ & $\begin{array}{c}\text { OPC, } \\
\text { Sercentage (\%) }\end{array}$ & $\begin{array}{c}\text { OPC } \\
\text { weight } \\
\text { percentage } \\
(\%)\end{array}$ \\
\hline $\mathrm{C}$ & 52.86 & 49.86 & - \\
$\mathrm{O}$ & 40.38 & 50.14 & 45.22 \\
$\mathrm{Al}$ & 1.56 & - & 1.23 \\
$\mathrm{Si}$ & 2.5 & - & 4.81 \\
$\mathrm{~S}$ & - & - & 1.31 \\
$\mathrm{Cl}$ & - & - & 1.69 \\
$\mathrm{Ca}$ & 0.48 & - & 25.39 \\
$\mathrm{Zr}$ & 2.22 & - & 2.38 \\
$\mathrm{Sb}$ & - & - & 17.96 \\
\hline Total & 100 & 100 & 100 \\
\hline
\end{tabular}

Meanwhile, Sago has no pozzolanic materials which are the element of Aluminum and silicon. The result obtained from EDX shows that sago is not suitable as pozzolans which can be used for stabilizing the peat. This is the main reason for the mix design of the peat sample with sago waste get a lower unconfined compressive strength if compare with the peat sample with pure cement. Lastly, calcium is the major elements contained in Ordinary Portland Cement as shown in Table 7.

The weight percentage of the element of treated and untreated peat are shown in Table 8. From this table, it can be found that the lower carbon, $\mathrm{C}$, and also higher Calcium, $\mathrm{Ca}$ weight percentage shows the better results of strength.

Table 8: EDX test results of untreated and treated peat

\begin{tabular}{ccccc}
\hline & $\begin{array}{c}\text { Untreated } \\
\text { peat, weight }\end{array}$ & \multicolumn{3}{c}{$\begin{array}{c}\text { Stabilized peat, weight } \\
\text { percentage (\%) }\end{array}$} \\
\cline { 3 - 5 } percentage & C100S0 & C75S25 & C80S20 \\
\hline $\mathrm{C}$ & 52.86 & & 24 & 60.23 \\
$\mathrm{O}$ & 40.38 & 45.22 & 40.05 & 35.31 \\
$\mathrm{Al}$ & 1.56 & 1.23 & 1.07 & 1.27 \\
$\mathrm{Si}$ & 2.5 & 4.81 & 3.68 & \\
$\mathrm{Cl}$ & & 1.69 & 1.06 & \\
$\mathrm{Ca}$ & 0.48 & 25.39 & 15.8 & 3.19 \\
$\mathrm{Zr}$ & 2.22 & 2.38 & & \\
$\mathrm{Sb}$ & & 17.96 & 11.9 & \\
$\mathrm{Other}$ & & 1.31 & 2.44 & \\
\hline Total & 100 & 100 & 100 & 100 \\
\hline
\end{tabular}

For example, the strength of the mix design of the peat increases from C80S20 to C75S25 and finally to C100S0 because of carbon and calcium weight percentages. The pozzolanic materials such as Aluminium and Silicon display changes slightly in treated peat because sago has no cementitious material 
and most of them have come from peat soils themselves as shown in Table 7.

\section{Scanning Electron Microscope (SEM)}
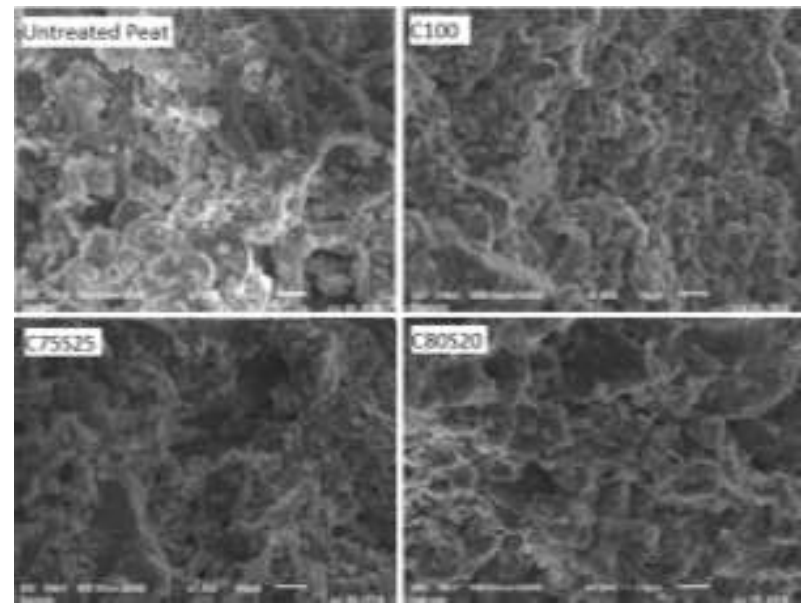

Figure 2: Scanning Electron Microscope (SEM) on treated and untreated peat

Figure 2 shows the result of the Scanning Electron Microscope on untreated and some of the treated peat. An obvious change can be observed when comparing the SEM results of treated and untreated peat samples. It can be observed that untreated peat samples consist of particles which is a very loose condition. The particles are hollow and spongy.

Minor void spaces can be detected in the SEM figure of stabilized peat specimens, which are C100 and C75S25. C100 peat specimen mixtures give much significant improvement in terms of tiny pore spaces and better compaction compare to C75S25. Meanwhile, peat mixtures of C80S25 show the loose condition of the particles in the peat specimen because it gives the lowest strength if compare to other mixed peat design specimens.

\section{CONCLUSION}

From the laboratory test, untreated peat soil taken from Tun Zaidi Stadium is peat soil with the classification of Hemic peat and degree of humidification of H5 by referring to the Von Post Classification Test, Organic Content Test, and Fiber Content Test. Peat soil in Tun Zaidi Stadium is acidic because of $\mathrm{pH}$ of less than 7. With higher water content, this soil is high compressibility and may lead to instability problems.

Utilization of Sago waste as partial cement replacement in Sibu peat stabilization has been determined. Sago waste cannot replace the cement partially in peat stabilization because it provides less unconfined compressive strength if compared to the original peat specimen made by cement itself. This is because sago waste has no pozzolanic materials such as aluminium and silica. However, ASTM 4609 states that an increase in unconfined compressive strength of 345 $\mathrm{kPa}$ or more must be achieved for a treatment to be considered effective.

In this study, the peat samples are taken at $1 \mathrm{~m}$ depth from the ground surface. Peat is classified as hemic thus, it contains lots of roots and rootlets that make the peat extraction using auger is exceedingly difficult at the deeper level. However, in future studies, it is recommended to take samples deeper if there is no difficulty during the peat sampling. The same methodologies can be applied to those samples at a deeper level.

For the Unconfined Compressive (UC) test, stabilized peat soil which is composed of $25 \%$ partially replacement of OPC with sago waste discovered to have peak unconfined compression strength of $840 \mathrm{kPa}$ and measured to be about 17 times higher than untreated peat sample. The optimum mix design is C75S25 because it gives better unconfined compressive strength compared to other stabilized peat.

To conclude, the target of an increase in UCS of $345 \mathrm{kPa}$ is considered a success because sago as a subbinder can stabilize untreated peat up to 17 times on the results of unconfined compressive strength. In conclusion, sago can treat the peat soil but not the best choices as pozzolans used to stabilize peat. There are inconsistency exists in the trend of the UCS, because of the effects of the carbon and calcium elements in the samples. More samples and testing should be done in the future to obtain relevant results for future references.

Energy Dispersive X-rays proved that lower carbon elements and higher calcium element gave better strength. SEM results of treated peat give more significant pore improvement compared to untreated peat. C75S25 mix composition is optimum mix design because it has higher calcium and lower carbon weight percentage compared to other mix composition.

It is recommended that related site investigations and laboratory tests need to be carried out to obtain more information on the pozzolans that suitable for the peat stabilization.

\section{ACKNOWLEDGEMENT}

The author gratefully thanks for financial support under the research grant UCTS/ RESEARCH/3/2019/03.

\section{REFERENCES}

[1] Davies, Jonathan. (2010). a Quick Scan of Peatland in Malaysia. Wetland International Malaysia, 1-80.

[2] Shenbaga R.Kaniraj, H.L.Huong. (2009). Electroosmotic consolidation studies on peat of north Sarawak. Indian Geotechnical Society, 455. 
[3] Ashraf E. Abdel-Salam. (2019). Stabilization of peat soil using locally admixture. HBRC journal, 294299.

[4] Drahansky, M. (2016) 'We are IntechOpen, the world' s leading publisher of Open Access books Built by scientists, for scientists TOP $1 \%$, Intech, i(tourism), p. 13. doi:http://dx.doi. org/10.5772/ 57353.

[5] Martinench, A. (2014) 'No Titles', Pontificia Universidad Catolica del Peru, 8(33), p. 44.

[6] Abu Talib, Mohd Khaidir. (2015). Effectiveness of Sugarcane Bagasse Ash (SCBA) as Partial Cement Replacement in Peat Stabilization. Memoirs of the Faculty of Engineering, Kyushu University, 69-78.

[6] Paikiey, Anil. (2017). Soil stabilisation using cement. International Journal of Civil Engineering and Technology, 316-322.

[7] Rodgers, L. (2018). Climate change: The massive CO2 emitter you may not know. Retrieved from BBC NEWS: https://www.bbc. com/news/scienceenvironment-46455844

[8] Awg-Adeni, D. S. et al. (2010) 'Bioconversion of sago residue into value added products', African Journal of Biotechnology, 9(14), pp. 2016-2021. doi: 10.4314/ajb.v9i14.
[9] Mohamad Naim, H., Yaakub, A. N. and Awang Hamdan, D. A. (2016) 'Commercialization of Sago through Estate Plantation Scheme in Sarawak: The Way Forward', International Journal of Agronomy, 2016. doi: 10.1155/2016/8319542.

[10] Department, S. R. (2013, Jun 16). Global Cement production 1990-2030. Retrieved from statista: https://www.statista.com/statistics/373845/globalcement-production-forecast/

[11] Youventharan Duraisamy, Bujang B.K. Huat and Azlan A. Aziz. (October 2007). Engineering Properties and Compressibility Behavior of Tropical Peat Soil. American Journal of Applied Sciences, 770.

[12] Duggan, A.R., B.A. McCabe, J. Goggins, E. Clifford. (2015). An embodied carbon and embodied energy appraisal of a section. Sciencedirect, 402-419. 